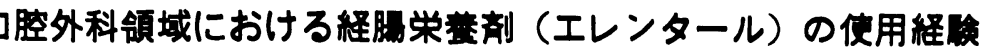

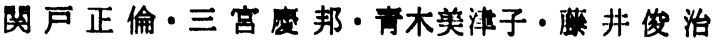 \\ 真中信之・山下泰裕・荻野経子・桑沢隆補 \\ 阿部広幸・扇内秀樹
}

\section{Clinical Application of Elemental Diet (Elental) in Oral Surgery}

\author{
Masanori Sekido • Yoshikuni Sangu • Mitsuko Aokı \\ Toshiharu FujII - Nobuyuki Manaka - Yasuhiro Yamashita \\ Tsuneko Ogino - Takaho Kuwazawa - Hiroyuki ABe \\ Hideki OgIuchI
}

\begin{abstract}
In past years, IVH has been the main method of nutritional management. However, as the management and surgical operation are complicated, recently Elemental Diet (ED) as a method of oral feeding has received great interest. In 1977, ED-AC (Elental) was developed for Japanese patients.

We examined the clinical symptoms and observations of 20 cases of ED-AC application. As a result, the clinical observations during the period of its application, showed a slight decrease in weight, serum proteins and serum albumine, but no significant changes in other tests.

Besides, among the 20 cases, 7 patients complained of diarrhea as side effect, but there was not a single case in which the application was suspended.

The clinical results in the application of ED-AC in the area of oral surgery showed in general an effective diet without causing serious side effects and with possibility of long-term application. It is concluded as being a valuable method.
\end{abstract}

Key words: nutritional management, elemental diet, enteral nutrition

\section{腥 \\ 言}

口腔外科領域の患者では, 術直後の経口的栄養摄取を 避けたい症例に道遇することがしばしばあり，このため 経静脈栄羡法や経管栄養法による栄湌管理が広く普及し ている.近年では経中心静脈高カロリー輸液(以下 IVH) が進歩してはいるものの管理や手技が複雑であり,また IVH 施行時の重篤な合併症も報告されている1 3)，この よらななかで最近管理が容易であり，臨床上経管的に高 カロリーの投与が可能で IVH に比べ生理的であり，か つ重䉆な合併症も少なく注目されている elemental-diet

東京女子医科大学口腔外科

（主任：扇内秀樹教授）

Department of Oral Surgery, Tokyo Women's Medical College (Chief: Prof. Hideki Ogiuchi)

受付日：昭和61年 7 月 9 日
(以下 ED) に関心が高まり ${ }^{4,5)}, 1977$ 年本邦であ日本人 に適した ED として ED-AC (エレンタール)か開発さ れだ)。今回，このェレンタールを用いた最近の症例を 対象として，臨床症状と臨床検査所見について検討を加 えたので報告する。

\section{対象ならびに方法}

\section{1. 対象症例}

対象症例は，東京女子医科大学口腔外科に入院した男 性14名, 女性 6 名の計 20 名で, 年龄は 16〜81 歳, 平均 31.7 葴である。疾患別では悪性腫瘍 7 例，䫑骨骨折 7 例, 䪽变形症 4 例, 下額骨骨䯣炎と口底蜂窩織炎がそれ ぞれ1例であった（表 1 ).

これら患者の手術後あるいは頻間固定中などの栄養補 給ならびに口腔内清潔維持を目的として投与を行い，投 与期間中の体重の増減および血液検査値の变動をもとに 
交 1 エレンタール投与症国

\begin{tabular}{|c|c|c|c|c|c|c|}
\hline 在例 & 年栺 & 性别 & 疶患名 & 応 & 投年 & $\begin{array}{c}\text { 平均投年 } \\
\text { 力 } 1 \text { J - } \\
(\mathrm{kcal} / \text { day) }\end{array}$ \\
\hline 1 & 16 & $\mathbf{M}$ & 下歌情折 & 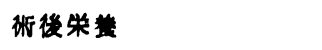 & 7 & 1,328 \\
\hline 2 & 29 & $\mathbf{M}$ & 上下静骨骨折 & 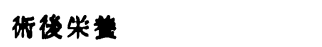 & 11 & 1,445 \\
\hline 3 & 20 & $\mathbf{M}$ & 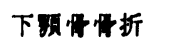 & 像後柴䢽 & 6 & 1,150 \\
\hline 4 & 17 & $\mathbf{M}$ & 下颔棏折 & 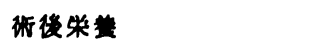 & 7 & 900 \\
\hline 5 & 27 & $\mathbf{F}$ & 下颗㥂折 & 街後柴素 & 4 & 675 \\
\hline 6 & 17 & $\mathbf{M}$ & 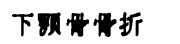 & 诉媵柴业 & 6 & 1,700 \\
\hline 7 & 24 & $\mathbf{M}$ & 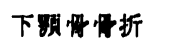 & 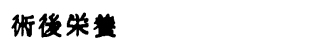 & 7 & 943 \\
\hline 8 & 51 & $\mathbf{M}$ & 海肉症 & 诲後柴衰 & 7 & 900 \\
\hline 9 & 42 & $\mathbf{F}$ & 上暴洞症 & 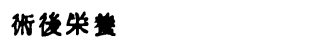 & 13 & 854 \\
\hline 10 & 81 & $\mathbf{M}$ & 上汤肉腰 & 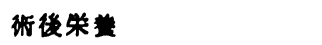 & 13 & 1,085 \\
\hline 11 & 65 & $\mathbf{M}$ & 㳄口蓝癌 & 経口提取困擎，采善管理 & 47 & 1,487 \\
\hline 12 & 49 & $\mathbf{F}$ & 舌病 & 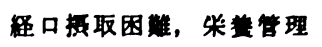 & 31 & 1,665 \\
\hline 13 & 68 & $\mathbf{M}$ & 肉癌 & 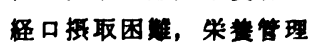 & 73 & 1,656 \\
\hline 14 & 38 & $\mathbf{M}$ & 舌病 & 経口摄取困嚾, 采裳管理 & 6 & 1,700 \\
\hline 15 & 22 & $\mathbf{M}$ & 新变形症 & 行後策善 & 5 & 900 \\
\hline 16 & 20 & $\mathbf{F}$ & 額変形症 & 继後策盖 & 9 & 1,200 \\
\hline 17 & 20 & $\mathbf{F}$ & 額变形症 & 行後类對 & 6 & 1,150 \\
\hline 18 & 27 & $\mathbf{M}$ & 影変形症 & 政後栄養 & 3 & 1,800 \\
\hline 19 & 58 & $\mathbf{F}$ & 下䫓骨骨链资 & 口腔内污染防止 & 4 & 1,321 \\
\hline 20 & 50 & $\mathbf{M}$ & 口医蜂蒚樴炎 & 経口摄取因䨀，采善管理 & 7 & 686 \\
\hline
\end{tabular}

表 2 投与前後の体重变化率

\begin{tabular}{c|c|c|c}
\hline 症例 & 投与前 $(\mathrm{kg})$ & 投与後 $(\mathrm{kg})$ & 比率 $(\%)$ \\
\hline 1 & 46.8 & 45.5 & 97.2 \\
2 & 52.0 & 52.0 & 100 \\
3 & 60.5 & 57.0 & 94.2 \\
4 & 58.0 & 55.5 & 95.7 \\
5 & 61.0 & 58.0 & 95.1 \\
6 & 56.0 & 55.0 & 98.2 \\
7 & 55.0 & 51.0 & 92.7 \\
8 & 69.0 & 64.0 & 92.8 \\
9 & 51.0 & 47.0 & 92.2 \\
10 & 51.0 & 47.0 & 92.2 \\
11 & 47.0 & 46.0 & 97.9 \\
12 & 41.2 & 39.5 & 95.9 \\
13 & 41.5 & 41.0 & 98.8 \\
14 & 35.0 & 31.0 & 88.6 \\
15 & 75.0 & 74.0 & 98.7 \\
16 & 54.0 & 53.5 & 99.1 \\
17 & 46.6 & 45.0 & 96.6 \\
18 & 49.0 & 47.0 & 95.9 \\
19 & 44.8 & 43.0 & 96.0 \\
20 & 52.0 & 48.5 & 93.3 \\
\hline
\end{tabular}

して，栄典効果を判定した。

\section{2. 投与方法}

エレンタール投与の浩度に関しては，消化器外科領域 の垁患に対する投与スケジュールクは特に考虑せず，1 日の投与回数を朝，昼，タの 3 回の間歇的投与とした。 投与日数，投与量は患者の状䈍によってさまさまで，最 短 3 日から最長73日で平均14.1日であった。 また1日の 平均投与カロリーは，最低 $675 \mathrm{kcal}$ から最高 $1,800 \mathrm{kcal}$ であり，症例により徐々に增量する投与法とした。 なお 初回投与量は 1〜2 pack (300〜600 kcal)/日とした（表 1).

$$
\text { 結果 }
$$

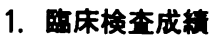

娭査はェレンタールの投与前, 中，後とした。検査項 目は, 体重 (BW), 血清㥹蛋白 (TP), 血清アルブミン (Alb), 赤血球数 (RBC), ヘマトクリット值 $(\mathrm{Ht})$, へ モクロビン量 $(\mathrm{Hb})$ ，血清奄解質 $(\mathrm{Na}, \mathrm{K}, \mathrm{Cl})$, 血清トラ ンスフミナーセ (GOT, GPT), 血中尿素空素 (BUN), クレアチニン (Creat) である.おのおのの検査値は, 平均値 (M)土標準偏差 (SD) で表した.

1) 体重 (BW), 血清総蛋白 (TP), 血清アルブミン (Alb) の推移（図1，表 2） 


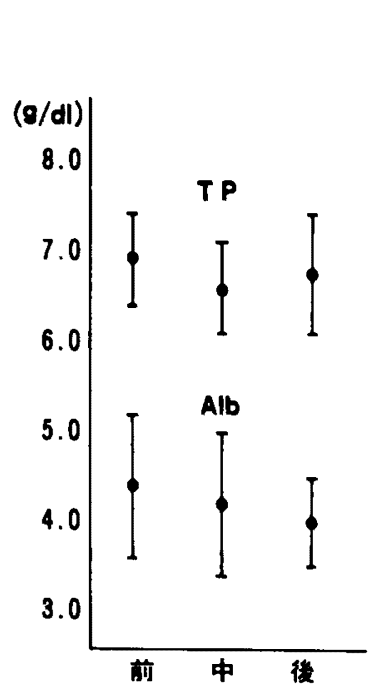

图 1 TP, Alb の推移

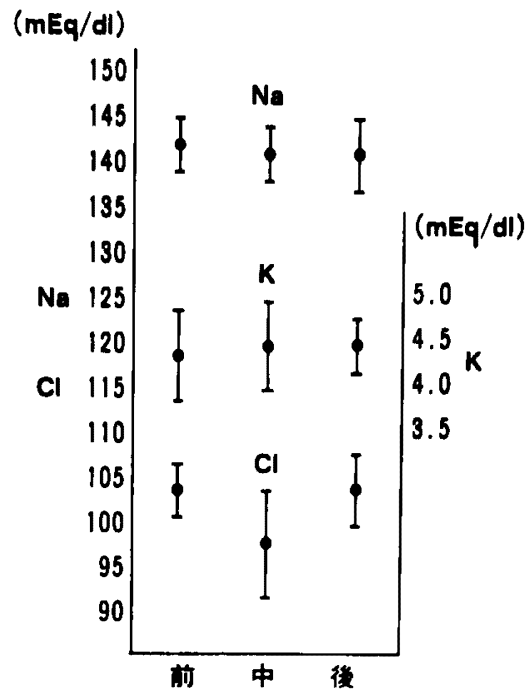

図 $2 \mathrm{Na}, \mathrm{K}, \mathrm{Cl}$ の推移

坡 3 臨床检查成維

\begin{tabular}{|c|c|c|c|c|c|c|c|c|c|}
\hline \multirow{2}{*}{ 項 目 } & \multicolumn{3}{|c|}{ RBC $\left(\times 10^{4}\right)$} & \multicolumn{3}{|c|}{$\mathrm{Ht}(\%)$} & \multicolumn{3}{|c|}{$\mathrm{Hb}(\mathrm{g} / \mathrm{d} l)$} \\
\hline & 前 & 中 & 挠 & 前 & 中 & 挠 & 前 & 中 & 後 \\
\hline 1 & 493 & 461 & 416 & 45.1 & 41.5 & 36.8 & 14.6 & 14.0 & 12.8 \\
\hline 2 & 437 & 394 & 450 & 39.2 & 35.8 & 40.5 & 13.3 & 12.2 & 13. 7 \\
\hline 3 & 443 & 424 & 421 & 40.8 & 38.1 & 37.7 & 13.3 & 12.7 & 12.9 \\
\hline 4 & 514 & 487 & 474 & 44.5 & 42.8 & 41.1 & 15.6 & 14.1 & 13.8 \\
\hline 5 & 414 & 415 & 420 & 37.1 & 37.1 & 37.5 & 12.6 & 12.3 & 12.7 \\
\hline 6 & 547 & 548 & 504 & 47.6 & 48.2 & 43.6 & 16.0 & 16.2 & 15.0 \\
\hline 7 & 472 & 416 & 391 & 43.2 & 37.6 & 35.1 & 14.4 & 13.1 & 12.1 \\
\hline 8 & 437 & 424 & 374 & 41.7 & 40.9 & 35.6 & 13.6 & 13.3 & 11.8 \\
\hline 9 & 413 & 377 & 395 & 37.0 & 33.4 & 34.5 & 12.1 & 11.0 & 11.2 \\
\hline 10 & 373 & 366 & 398 & 33.1 & 32.4 & 35.8 & 10.7 & 10.5 & 11.6 \\
\hline 11 & 284 & 289 & 333 & 32.5 & 29.3 & 34.0 & 10.8 & 9.6 & 11.1 \\
\hline 12 & 367 & 290 & 249 & 33.9 & 25.4 & 21.4 & 11.0 & 8.4 & 7.4 \\
\hline 13 & 288 & 108 & 351 & 27.6 & 32.4 & 34.1 & 9.2 & 10.8 & 11.4 \\
\hline 14 & 451 & 480 & 372 & 38.6 & 42.4 & 32.2 & 12.3 & 13.1 & 10.3 \\
\hline 15 & 490 & 441 & 425 & 46.4 & 41.6 & 39.2 & 15.6 & 13.7 & 12.8 \\
\hline 16 & 463 & 398 & 440 & 43.6 & 36.4 & 40.1 & 14.2 & 12.5 & 13.6 \\
\hline 17 & 425 & 361 & 429 & 38.8 & 33. 1 & 39.0 & 12.8 & 11.4 & 13.0 \\
\hline 18 & 547 & 523 & 451 & 48.4 & 41.6 & 39.7 & 15.9 & 14. 2 & 13. 3 \\
\hline 19 & 423 & 383 & 366 & 32.6 & 29.7 & 26.5 & 10.0 & 9.2 & 9.0 \\
\hline 20 & 529 & 449 & 432 & 48.4 & 40.8 & 39.4 & 15.5 & 13.2 & 12.8 \\
\hline mean & 441 & 402 & 405 & 40.0 & 36.9 & 36.2 & 13.2 & 12.8 & 12.1 \\
\hline $\mathrm{SD}( \pm)$ & 72 & 93 & 54 & 5.8 & 5.4 & 5.0 & 2.0 & 1.9 & 1.7 \\
\hline
\end{tabular}




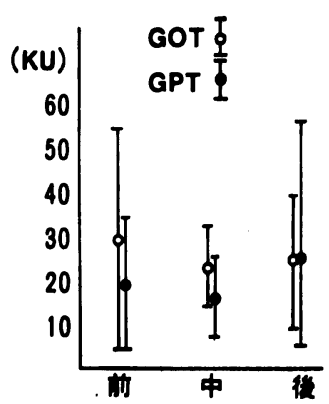

图 3 GOT, GPT の推移

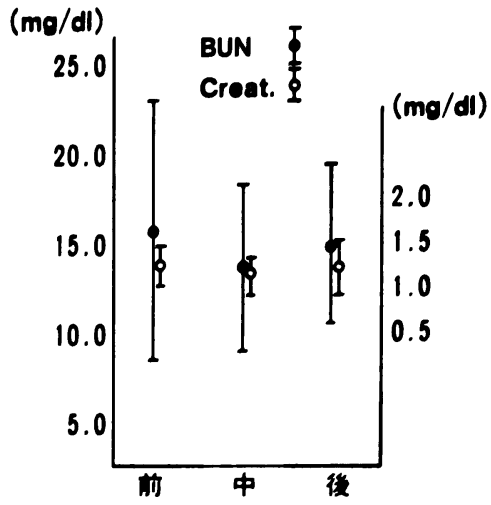

图 4 BUN, Creat. の推移

表 4 ED-AC 組成夷

\begin{tabular}{|c|c|c|c|}
\hline \multicolumn{4}{|c|}{ a. フミノ酸 (17.611\%) } \\
\hline L-Ile & $0.803 \%$ & L-Ala & $1.124 \%$ \\
\hline L-Leu & 1.124 & $\mathrm{~L}-\mathrm{Arg} \cdot \mathrm{HCl}$ & 1.406 \\
\hline L-Lys $\cdot \mathrm{HCl}$ & 1.110 & L-Asp $\cdot \mathrm{Na} \cdot \mathrm{H}_{2} \mathrm{O}$ & 1.084 \\
\hline L-Met & 0.810 & $\mathbf{L}-\mathbf{A s p} \cdot \mathbf{K} \cdot \mathbf{M g}$ & 1.295 \\
\hline L-Phe & 1.089 & L-Gln & 2.415 \\
\hline L-Tyr & 0.138 & Gly & 0.631 \\
\hline L-Thr & 0.654 & $\mathrm{~L}$ - $\mathrm{His} \cdot \mathrm{HCl} \cdot \mathrm{H}_{2} \mathrm{O}$ & 0.626 \\
\hline L-Trp & 0.189 & L-Pro & 0.788 \\
\hline L-Val & 0.876 & L-Ser & 1.449 \\
\hline (EAA) & (6. 793) & (NEAA) & (10.818) \\
\hline
\end{tabular}

b. 炭水化物 $(79.373 \%)$

デキストリン

79. $373 \%$

\begin{tabular}{cl}
\hline c. 脂 質 $(0.657 \%)$ & \\
soy bean oil & $0.636 \%$ \\
レシチン & 0.021
\end{tabular}

d. 電解質 $(2.02 \%)$

グルコン酸鉄・2 $\mathrm{H}_{2} \mathrm{O}$

硫酸銅・5 $\mathrm{H}_{2} \mathrm{O}$

$194 \mathrm{ppm}$

硫酸マンガン・5 $\mathrm{H}_{2} \mathrm{O}$

1.03

16. 31
酷酸垔鲐・ $2 \mathrm{H}_{2} \mathrm{O}$

75.07

ヨウ化カリウム

0.245

塩化カリウム

0. $188 \%$

クーン酸ナトリウム・2 $\mathrm{H}_{2} \mathrm{O}$

0.770

クリセロリン酸カルシゥム

1.031

e. ピタ ミン (1646.9 ppm)

酢酸レチノール $\quad 10,000 \mathrm{Iu} / \mathrm{g} \quad 810.0 \mathrm{ppm}$

埴酸子フミン 2.42

リン酸リポフラピン・Na 3.20

㙁酸ピリドキシン

シフノコラミン 9.00

フスコルピン酸

エルコカルシフェロール $\quad 0.016$

酢酸トコフェロール20\% 206.3

ビタミン $\mathrm{K}_{1}$

パントテン酸 $\mathrm{Ca} \quad 14.9$

ニコチン酸アミド10\% 275.0

ビオチン

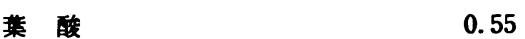

重酒石酸コリン 224.1
BW は投与前 $52.3 \pm 8.4 \mathrm{~kg}$ ，投与中 $51.1 \pm 9.2 \mathrm{~kg}$, 投与終了後 $50.0 \pm 9.1 \mathrm{~kg}$ と徐々に減少㑯向を示した. これは，口腔外科領域では特に術後の栄養補給を目的と する場合が多く，長期の投与例が少ないことから，短期 間での体重の増加傾向はみられなかったといえる．また 各症例の投与前後の BW の変化率は表 2 のごとくであ る. $\mathrm{TP}$ では投与前 $6.8 \pm 0.5 \mathrm{~g} / \mathrm{d} l$, 中 $6.5 \pm 0.5 \mathrm{~g} / \mathrm{d} l$, 後 $6.6 \pm 0.6 \mathrm{~g} / \mathrm{d} l$ であり，また Alb においても前 4.3 $\pm 0.8 \mathrm{~g} / \mathrm{d} l$, 中 $4.1 \pm 0.8 \mathrm{~g} / \mathrm{d} l$, 後 $3.9 \pm 0.5 \mathrm{~g} / \mathrm{d} l$ と,
いずれるやや減少を示したものの正常筑囲内であった.

2 ）赤血球数 (RBC), ヘマトクリット值 $(\mathrm{Ht})$, 人 モグロピン量 (Hb) の推移 (交3)

RBC は前 $441 \pm 72 \times 10^{4}$, 中 $402 \pm 93 \times 10^{4}$. 後 $405 \pm$ $54 \times 10^{4}, \mathrm{Ht}$ は前 $40.0 \pm 5.8 \%$ ，中 $36.9 \pm 5.4 \%$ ，後 $36.2 \pm 5.0 \%, \mathrm{Hb}$ は前 $13.2 \pm 2.0 \mathrm{~g} / \mathrm{d} l$, 中 $12.8 \pm 1.9$ $\mathrm{g} / \mathrm{d} l$, 後 $12.1 \pm 1.7 \mathrm{~g} / \mathrm{d} l$ であり，いずれにおいてるほ ぼ正常籍囲内であるが，わずかながら投与中に減少がみ られた。 


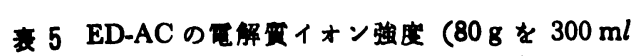
に溶解，フミノ酸，有賎酸をのぞく）

\begin{tabular}{ll|ll}
\hline \multicolumn{2}{c|}{ cathion } & \multicolumn{2}{c}{ anion } \\
\hline $\mathrm{Na}$ & $37.7 \mathrm{mEq} / l$ & $\mathrm{Cl}$ & $48.7 \mathrm{mEq} / l$ \\
$\mathrm{~K}$ & 18.6 & $\mathrm{SO}$ & 0.06 \\
$\mathrm{Mg}$ & 11.0 & $\mathrm{I}$ & 0.00039 \\
$\mathrm{Ca}$ & 26.2 & $\mathrm{P}$ & 39.3 \\
$\mathrm{Fe}$ & 0.215 & & \\
$\mathrm{Cu}$ & 0.024 & & \\
$\mathrm{Mn}$ & 0.036 & & \\
$\mathrm{Zn}$ & 0.189 & & \\
\hline
\end{tabular}

\section{3）血清奄解留 ( $\mathrm{Na}, \mathrm{K}, \mathrm{Cl}$ ) の推移（図 2)}

エレンタール投与中におけるて解筫代新の推移は，そ れぞれ $\mathrm{Na}:$ 前 $141 \pm 3 \mathrm{mEq} / \mathrm{d} l$, 中 $140 \pm 3 \mathrm{mEq} / \mathrm{d} l$, 後 $140 \pm 4 \mathrm{mEq} / \mathrm{d} l, \mathrm{~K}:$ 前 $4.3 \pm 0.5 \mathrm{mEq} / \mathrm{d} l$, 中 $4.4 \pm 0.5$ $\mathrm{mEq} / \mathrm{d} l$, 後 $4.4 \pm 0.3 \mathrm{mEq} / \mathrm{d} l, \mathrm{Cl}:$ 前 $103 \pm 3 \mathrm{mEq} / \mathrm{d} l$, 中 $97 \pm 6 \mathrm{mEq} / \mathrm{d} l$, 後 $103 \pm 4 \mathrm{mEq} / \mathrm{d} l$ であり, 龟解質代 謝の変動はほとんどなくいす゚れる正常筑囲内であった。

4) 血清トランスアミナーセ（GOT, GPT) の推移

\section{(因3)}

GOT, GPT の投与前, 中，後の值はそれぞれ $29 \pm 25$ $\mathrm{KU}, 23 \pm 9 \mathrm{KU}, 24 \pm 15 \mathrm{KU}$, および $19 \pm 15 \mathrm{KU}, 16 \pm$ $9 \mathrm{KU}, 25 \pm 30 \mathrm{KU}$ であり, 特に異常变動はみられなか った.

5) 血中尿素窒素 (BUN)， クレアチニン (Creat) の 推移（図4)

BUN は $15.6 \pm 7.2 \mathrm{mg} / \mathrm{d} l, 13.5 \pm 4.7 \mathrm{mg} / \mathrm{d} l, 14.8 \pm$ $4.5 \mathrm{mg} / \mathrm{d} l$, Creat は $1.2 \pm 0.2 \mathrm{mg} / \mathrm{d} l, 1.1 \pm 0.2 \mathrm{mg} / \mathrm{d} l$, $1.2 \pm 0.3 \mathrm{mg} / \mathrm{d} l$ であり，投与中におけろ堅機能障害を 認めた症例はなく, 問題なく経過した。

以上, ェレンタール投与中における代謝変動について は，特筆すべき事項は認められなかった。

\section{2. 酛床的副作用}

エレンタール投与による副作用として，下峲，腹部膨 满感, 腹痛, 悪心, 嘔吐について钼察したが, 下峲が20 例中 7 例で，そのうち 4 例は投与終了後も数日続いた. また腹部膨満感を訴えたるのは20例中 5 例であったが, 投与を中止するよらな重篤な副作用はみられなかった。

\section{考察}

エレンタールは, 五大栄養素が消化された形で配合さ れた経腸栄養剤であり，その成分組成は表 4 のごとくで ある、本刜は腸管から速やかに吸収されて，必須な栄養 素をハランンスく供給し，また無残椬性であり，下蔽が 少なく，高カロリー投与が可能である.

ヘレンタールのアミノ酸組成は卵白アルブミンのアミ

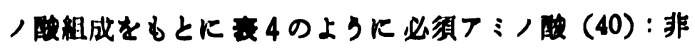

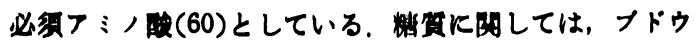

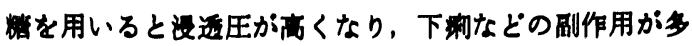
くなることが危惧されるため本詴ではデャストリンを使

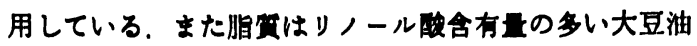

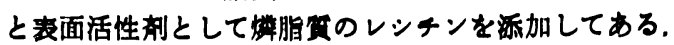

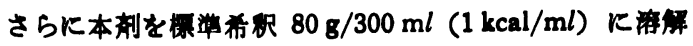
した场合のイオン強度は事 5 のことくであり，微步元来 については Zn などがやや多めに含まれている．ビタミ ン類は日本人の 1 日必法年として十分な五が含まれてい ろ。).

また、エレンタールは，全ての被成分が化学的に明 確であるため，いくつかの利点をるっている，まず，监 純な物賈の混合であるため溶解が容易でチューブあかな り内径の細いるのです注入可能である. したがって経基 的に括入する场合の手技が容易であり，患者の苦痛す少 ないといえる，また，前述の衰 4 のことく，組成の明ら かな成分であり，消化を必要とせず，ほとんど上部消化 管で吸収されるため，消化吸収能力の低下した症例にお いても，消化液分泌の刺做がなく，少ない投与旦で従来

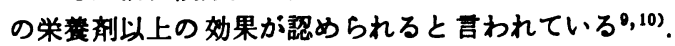
さらに IVH とおのおのの特性を比校してみると，とも に高カロリー投与が可能であり糖缶を主熟源としてい ろ. IVH 。成分栄养消化液分泌は通常の経口摄取に 比べ大幅に減少する，また，IVH では排便がなくなる が，成分栄養では極端に減少するがわずかながらにみら れ，粘液便のような軟便が少しずつみられる．合併症に 関しては，IVH では手技的な問題でカテーテル插入時 やカテーテル留置中に発生しているか，成分栄倠ではか なりチューブの内径が細いため, 挿入時や留置後す管理 が非常に容易である，しかし，代碀面では主等源が榶質 であるため，IVH と同様に高血糖や糖尿等に油意しな ければならない，最近では合併症として，EDによる高 浸透压性非ヶトン性糖尿昏睡の発生報告されてお $\eta^{11,12)}$ ，投与中の注意が必要である.

われわれの症例においてほとんどが短期間の投与であ り，平均投与カロリーむ $1,800 \mathrm{kcal}$ 以下とい5こともあ り, 体重, 血清総蛋白, 血清アルブミンなどにおいてゃ や減少がみられたが正常範囲内であるので，口腔外科領 域での使用には十分なるのといえる。 さらに、ェレンタ 一ル投与時における投与速度, 投与濃度, 投与時温度な どへの考慮を怠ると, 副作用特に下峲の発生頻強は高く なると思われる ${ }^{13,14)}$. 今回の使用例です20例中 7 例と 35 \%に下峲の発生をみたが，この副作用への対処として暫 時投与量を調整していくことで投与を継続した。 すなわ ち，ある程度慣れてしまらと下浰の発生す少なくなり， 小越ら ${ }^{15)} 1$ 日 $2,400 \mathrm{kcal}$ 前後に維持されてる，投与速 度が $130 \mathrm{ml} / \mathrm{hr}$ を越えない方が安全と述べている。また 一般消化器外科などの使用経験において，血清トランス 
フミナーセ（GOT, GPT) の一過性の上界がみられてい るが，上腹部の手㧓による判潄に上るるのが多く、ニレ ンタールにははとんと影新されていない18，17)。しかし肝 機能への影整や血粘の上界などには注意が，必要と思われ

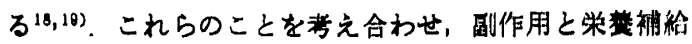
との間には，投与是，投与速度などによって左右される ものであり，今後いくつかの確立したスケジュールが必 要と思われた。

\section{結铻}

口腔外科颃城の術直後の栄粪管理を主目的としてェレ

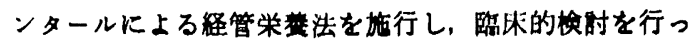
た結果，検査值において特に投与に上って大きな变化を 示したものはなく，総合的に十分な栄举奻果が熟められ た．肝機能，督機能などへの著明な影缡むなく，時に下 制などの消化器症状を煏めたか，中止に至った症例はな かった．また，長期投与る可能でありエレンタールによ る経腸栄隻法は有意なものといえる。

\section{引用 文 献}

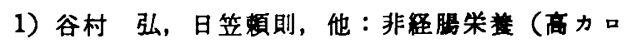
リ一榆液)の適底と合併症. 外科 Mook 3: 1161321972.

2) 風田正, 山本裕, 他: 高力ロリ一錸液 (N) 肺血症. 外科治 30：205-208 1974.

3) Ryan, J.A. Jr.: Complications of total parenteral nutrition, ed. Fisber J.E., p 55, Little, Brown and Company, Boston, 1976.

4) Greenstein, J.P. and Otey, M.C.: Quantitative nutritional studies with water soluble, chemically defined diets. J Nati Can Inst 24: 2112191960.

5) Winitz, M., Seedman, D.A., et al.: Studies in metabolic nutrition emplaying chemically defined diets. Amer J Clin Natr 23: 525-545 1970.

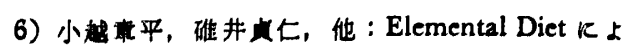
万䌅的 hyperalimentation ( I ) 一新品の 閁発について—。外科 40: 913-915 1978.

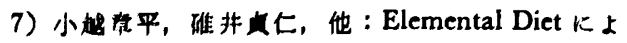
万猛腈的 hyperalimentation (II) 一投与方 法について一一。外科 40: 991-994 1978.

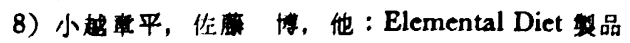
(ED-AC) Кついて，医学のおゆみ 106: 26-28 1978.

9）木下㤑宏，井出博子，他：上部消化器能患者の

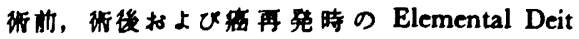

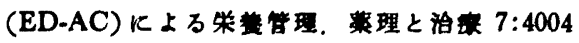
$-40151979$.

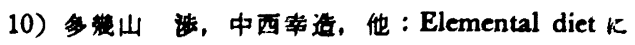

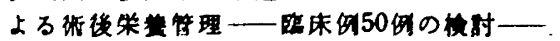
整理と治康 7：3647-3656 1979.

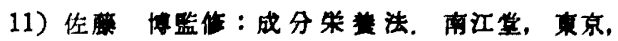
1981，142-143面.

12）永田早苗, 高田忠数，他：Elemental Diet 投与 中に発生した Nonketotic Hyperoumolar Coma の 1 例. 東女医大踗 49: 1111-1116 1979.

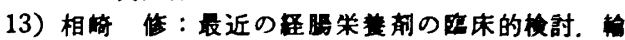
液栄黄ジャーナル 5: 735-738 1983.

14）菅原利夫，幸雅烓，他：口腔外科湎城におけ

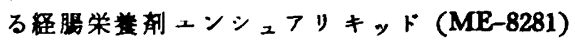
の度床広用(第 2 報). 日只外誌 30 : 1634-1643 1984.

15）小地章平, 碓井貞七, 他 : Elemental Diet Kよ 万経渴的 Hyperalimentation (IV) 一聂作用 にっいて—. 外科 40: 1470-1472 1978.

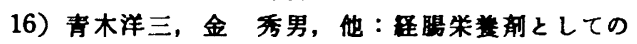
Elemental Diet (ED-AC) Low Residue Diet

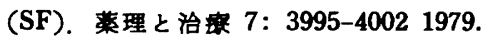

17）相场哲郎, 吉川和子, 他 : ED-AC の使用経䠯。 莫理と治理 8：2429-2437 1980.

18）小田原良治，浜田映，他：Elemental Diet よる栄养管理—ED分棓投与法について一一。 外科診瘄 22: 918-922 1980.

19）大ケ瀨浩史, 児玉厚雄, 他: 成分栄䖭都を底用 した口腔外科湎城患者比対す万栄美管理。日口 外誌 29: 941-949 1983. 